\title{
Coastal inundation modeling and mapping for North Jakarta coast during a supermoon period
}

\author{
Nelly Florida Riama ${ }^{1, *}$, Riri Fitri Sari ${ }^{2}$, Widada Sulistya ${ }^{4}$, Henita Rahmayanti ${ }^{3}$, Khafid Rizki Pratama ${ }^{4}$, \\ Bayu Edo Pratama ${ }^{4}$, and Arief Wibowo Suryo ${ }^{4}$ \\ ${ }^{1}$ School of Environmental Science, Universitas Indonesia, Jakarta, Indonesia \\ ${ }^{2}$ Faculty of Engineering, Universitas Indonesia, Depok, Indonesia \\ ${ }^{3}$ Faculty of Engineering, Jakarta State University, Jakarta, Indonesia \\ ${ }^{4}$ Meteorological, Climatological, and Geophysical Agency, Kemayoran, Jakarta Pusat, Indonesia
}

\begin{abstract}
Article history:
Received 13 September 2020

Revised 15 January 2021

Accepted 2 April 2021

Keywords:

North Jakarta, Supermoon, Water level, Delft3D, Coastal inundation, Early warning

Citation:

Riama, N. F., R. F. Sari, W. Sulistya, H. Rahmayanti, K. R. Pratama, B. E. Pratama, and A. W. Suryo, 2021: Coastal inundation modeling and mapping for North Jakarta coast during a supermoon period. Terr. Atmos. Ocean. Sci., 32, 375-390, doi: 10.3319/TAO.2021.04.02.01
\end{abstract}

\begin{abstract}
Coastal areas are very vulnerable to disasters. One of the disasters that needs serious attention in coastal areas, including the coast of Jakarta, is coastal inundation. However, there is no integrated coastal inundation prediction system implemented in this area. This study aimed to build a model of coastal inundation by combining various factors, namely hydrodynamic model, wave model, and river model. The model used in this research is the integration of the Delft3D model, the WaveWatch III-SWAN model, and the SOBEK model. The results show that the simulation of the water level was in accordance with the observed data, from 30 November to 8 December 2017 during the supermoon period with a correlation accuracy of 0.9 and RMSE of $5.9 \mathrm{~cm}$. However, the results of the simulation and astronomical tide prediction have a correlation of 0.81 and an RMSE is $13.6 \mathrm{~cm}$. Therefore, it can be seen that the model is better than the astronomical tide prediction. The hydrodynamic model shows that Jakarta Bay has a water level range of 0.66 to $0.68 \mathrm{~m}$ during the supermoon period. The mapping of flood inundation areas show that the water level in the Tanjung Priok and Marunda in North Jakarta has a maximum inundation level of 50 to $100 \mathrm{~cm}$ with an inundation area of 272.17312 and $456.03653 \mathrm{~m}^{2}$. Meanwhile, our analysis for the Ancol and Kalibaru shows an inundation level of 0 to $30 \mathrm{~cm}$ with an inundation area of 388.04358 and $169.17656 \mathrm{~m}^{2}$. Our model provides better accuracy because it takes into account several important variables for modeling coastal inundation. Our early warning system proved to be accurate in providing coastal inundation prediction information for the North Jakarta area.
\end{abstract}

\section{INTRODUCTION}

A coastal area is a place where various kinds of social, economic and political activities interact with natural processes (De Alencar et al. 2020), which are highly influenced by environmental changes. The exposure of coastal communities to economic losses as a result of coastal inundation is expected to increase in the coming centuries due to environmental and socio-economic changes (Rimbaman and Suparan 1999; IPCC 2007; Nicholls et al. 2010). The most obvious example of an area requiring important information regarding the damage caused by coastal inundation is In-

\footnotetext{
* Corresponding author

E-mail: nelly.florida@ui.ac.id
}

donesia. Indonesia is the largest archipelagic country in the world, with a coastline of $99.093 \mathrm{~km}$ and a total of 17.508 islands in which more than 1500 islands are threatened due to rising sea levels, i.e., Indonesia is very vulnerable to coastal disaster (Farhan and Lim 2010). On the other hand, a study by Takagi et al. (2016) assumed that the sea-level throughout Indonesia will continue to rise at a $7 \mathrm{~mm}_{\text {year }}{ }^{-1}$ and ultimately will amount to a $35 \mathrm{~cm}$ difference between 2000 and 2050. Land subsidence, combined with sea-level rise, heavy rains, storms and flood runoff from rivers, will expand the areas prone to coastal inundation in cities in Indonesia's coastal areas (Ericson et al. 2006; Chaussard et al. 2013). One of the cities in Indonesia, Jakarta with is also 
of cities most vulnerab to coastal inundation. Jakarta is irrigated by 13 rivers and $40 \%$ of its land is under high-tide conditions (Rosenzweig and Solecki 2001; Putuhena and Ginting 2013).

Jakarta has a substantial record of floods caused by various factors such as heavy rain, river overflow, and maximum tides. In 2007, North Jakarta experienced both a maximum tide and heavy rainfall, affecting a total area of $400 \mathrm{~km}^{2}$ (Bappenas 2007). From this fact, it can be seen that coastal inundation is not only caused by oceanographic and tidal components but atmospheric force. This phenomenon poses a threat to metropolitan areas such as the North Jakarta municipality. It is estimated that the frequency of coastal floods will gradually increase and affect significant land areas in the future (Marfai 2013).

The lack of a specific disaster management system or a coastal inundation early warning system, especially for the Jakarta area, is the motivation for this work. Generally, coastal inundation early warning systems in Indonesia are simple and involve calculating the water level in the river's upstream area. Ginting and Putuhena (2014) reported that a specific floods early warning system due to river overflows was being developed in 2014 through the Delft-Flood Early Warning System (FEWS), also known as Jakarta-FEWS (J-
FEWS). However, this early warning system model is not sufficient for coastal areas because it does not consider the components of water level changes from the sea and tide. Therefore, it is necessary to create a model that integrates the components that affect coastal inundation. For the case of Jakarta, it is necessary to consider the complex factors that cause coastal inundation.

Developing a coastal inundation model involve components from both the sea and land. The model used in this research is the Delft3D model, which includes the hydrodynamic model, the wave model, using the WaveWatch IIISWAN model, and the river flow model, using the SOBEK model. It is hoped that this model can provide more accurate coastal inundation information to be used as a coastal inundation early warning system in North Jakarta.

\section{STUDY AREA}

The province of the Special Capital Region of Jakarta [local term: Daerah Khusus Ibukota Jakarta (DKI Jakarta)] is a lowland zone with an average height of $\pm 7 \mathrm{~m}$ above sea level. DKI Jakarta Province is bordered by the coast from west to east for $\pm 35 \mathrm{~km}$ into the north (see Fig. 1).

The coastal area is the estuary for 13 rivers that borders

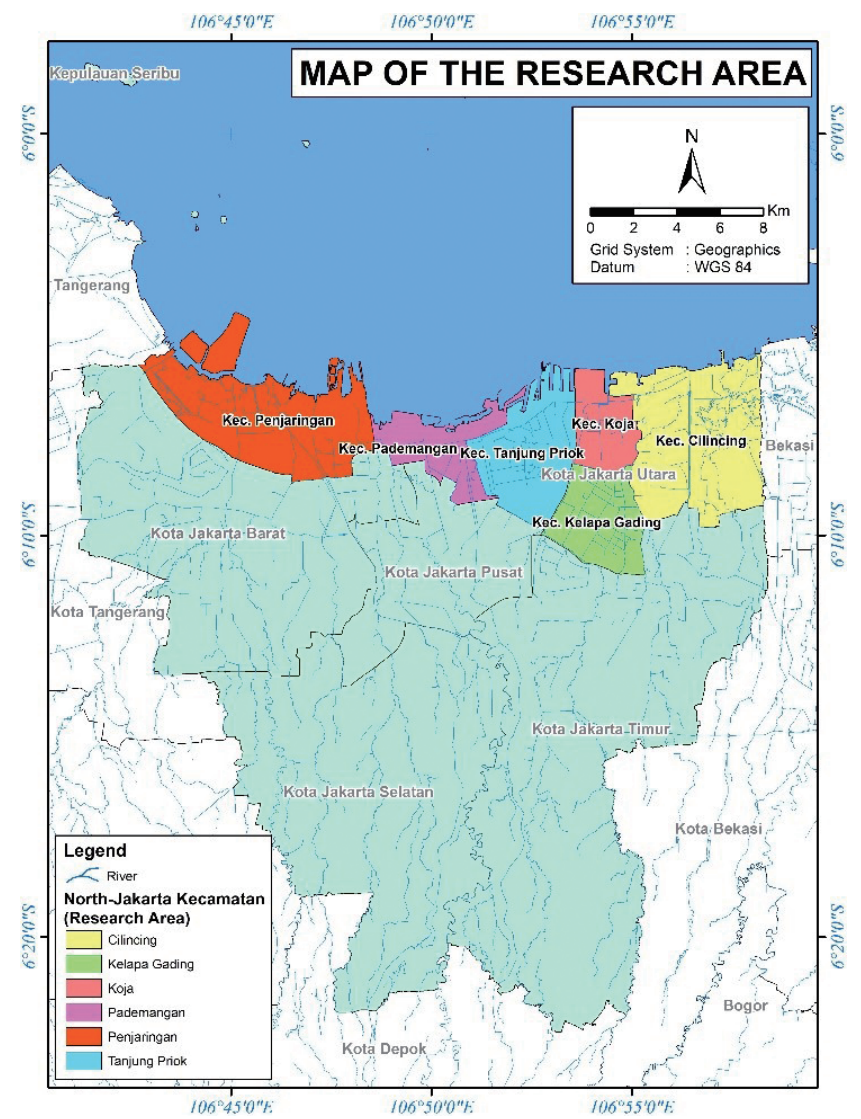

Fig. 1. Research area: North Jakarta City, Daerah Khusus Ibukota (DKI) Jakarta Province, Indonesia. (Source : Rupa Bumi Indonesia, BIG). 
the Java Sea. To the west, this location is bordered by Banten Province, and on the south and east it borders West Java Province. North Jakarta is very vulnerable to coastal inundation due to its location which is directly adjacent to the sea and has experienced significant land subsidence over the past few years. In this study, the focus of research is North Jakarta, which administratively belongs to the Municipality of North Jakarta. The area of North Jakarta itself is $146.66 \mathrm{~km}^{2}$. The height above sea level is between 0 and $2 \mathrm{~m}$, while certain places are located below sea level. Administratively, North Jakarta consists of six sub-districts, namely: Cilincing, Kelapa Gading, Koja, Pademangan, Penjaringan, and Tanjung Priok districts, with an area of 39.70, 14.87, 12.25, $11.92,45.41$, and $22.52 \mathrm{~km}^{2}$.

\section{METHODOLOGY}

This research took place between 30 November to 8 December 2017, which coincided with the supermoon events that occurred from 3 to 5 December 2017 (NASA 2017). As already mentioned, the model in this study was developed from the Delft3D, WaveWatch III-SWAN, and SOBEK models. Our methodology consists of two steps: (1) the development of three models to build a single integrated system, namely Delft-FEWS or Jakarta-FEWS; (2) the creation of an inundation map in the North Jakarta used Geographic Information System (GIS).

\subsection{Waves-Hydrodynamic and Hydrology Models}

WaveWatch III (WWIII) is a third generation wave model developed by National Centers for Environmental Prediction (NCEP) in the Limited Area Model (LAM) (Komen et al. 1994; Tolman et al. 2014). This wave model takes into account the nonlinear wave calculation indirectly without parameterization (Takagi et al. 2016). The third-generation wave model equation has applied spectrum calculations to obtain the wavenumber as follow:

$S=S_{i n}+S_{n l}+S_{d s}+S_{b o t}$

where the net source term $S$ is generally considered to consist of three parts, a wind-wave interaction term $S_{i n}$, a nonlinear wave-wave interaction term $S_{n l}$, and a dissipation ('whitecapping') term $S_{d s}$. The input term $S_{i n}$ is dominated by the exponential growth term, and this source term generally describes this dominant process only. For model initialization, and to provide more realistic initial wave growth, a linear input term $S_{i n}$ can also be considered in WaveWatch III by Eq. (1). The wave value from WaveWatch III is used as the boundary value in the Simulating Waves Nearshore (SWAN) model. SWAN is the third generation near-shore wave action model designed to overcome the traditional difficulties of using global wave models such as WW3 in coastal regions. It uses typical formulations for wave growth by wind, wave dissipation by white-capping, and four wave nonlinear interactions (quadruplets or quads) (Sampurno 2001). In Cartesian coordinates, it is given by:

$S_{t o t}=S_{i n}+S_{n l 3}+S_{d s, w}+S_{d s, b}+S_{d s, b r}$

where, in shallow water additional processes have to be considered, most notably wave-bottom interactions $S_{b o t}$. In extremely shallow water, depth-induced breaking $\left(S_{d s, b}\right)$, and triad wave-wave interactions $\left(S_{d s, b r}\right)$ become important [see Eq. (2)].

Delft3D models are integrated modeling that simulates two-dimensional (horizontal and vertical planes) and threedimensional flows, sediment transport and morphology, waves, water quality, and ecology (Deltares 2010). In the Delft3D model, 2D and 2D + grid models are developed using several formulations such as St. Venant, hydrostatic pressure distribution formula and Boussinesq formula (Hervouet and Van Haren 1996), in which $V_{v}$ is the vertical turbulent eddy viscosity and the horizontal pressure terms $P_{x}$ and $P_{y}$ for a certain depth $\mathrm{z}$ can be determined by (Boussinesq approximations):

$$
\frac{\partial u}{\partial x}+\frac{\partial v}{\partial y}+\frac{\partial w}{\partial z}=0
$$

$\frac{\partial u}{\partial t}+\frac{\partial u}{\partial x}+\frac{\partial u v}{\partial y}+\frac{\partial u w}{\partial z}-$

$f v+\frac{1}{\rho 0} P x-F x-\frac{\partial}{\partial z}\left(V v \frac{\partial u}{\partial z}\right)=0$

$\frac{\partial v}{\partial t}+\frac{\partial v u}{\partial x}+\frac{\partial v v}{\partial y}+\frac{\partial v w}{\partial z}-$

$f v+\frac{1}{\rho 0} P y-F y-\frac{\partial}{\partial z}\left(V v \frac{\partial u}{\partial z}\right)=0$

Meanwhile, the river model used to construct river conditions in the Jakarta area is the SOBEK model. The SOBEK model simulates river currents and flows, including river runoff. The SOBEK model has the ability to pair rainfall models with hydrodynamic models and wave models. The SOBEK model's output consists of inundation area, water depth, water quality, and depth average velocity (Deltares 2010). The SOBEK model used here was developed as a warning system for floods caused by river flows or overflows (Ginting and Putuhena 2014). The equation used in the SOBEK model's numerical concept is based on the distribution of inundation modeling criteria, namely overland flow (SOBEK-2D) and channel flow (SOBEK-1D). The 
solution of this equation using de Saint Venant's formulation is as follows:

$\frac{\partial A_{f}}{\partial t}+\frac{\partial Q}{\partial x}=q_{\text {lat }}$

$\frac{1}{g A}\left\{\frac{\partial Q}{\partial t}+\frac{\partial}{\partial x}\left(\frac{Q^{2}}{A_{f}}\right)\right\}+\frac{\partial \zeta}{\partial x}+\frac{Q|Q|}{K^{2}}=0$

where, $A_{f}$ is wet area $\left(\mathrm{m}^{2}\right)$, and $q_{\text {lat }}$ is lateral discharge per length. These two components are used in conjunction with a time $(s)$ in $t$, distance (m) in $x$ and river discharge $(Q)$. Meanwhile, Eq. (7) is the momentum equation from Eq. (6), which is used in the 1-D formula. The $2 \mathrm{D}$ continuity equation is as follows (Deltares 2010):

$\frac{\partial \zeta}{\partial t}+\frac{\partial(u h)}{\partial x}+\frac{\partial(v h)}{\partial y}=0$

$\frac{\partial u}{\partial t}+u \frac{\partial u}{\partial x}+v \frac{\partial v}{\partial y}+g \frac{\partial \zeta}{\partial x}+g \frac{u|V|}{C^{2} h}+a u|u|=0$

$\frac{\partial v}{\partial t}+u \frac{\partial v}{\partial x}+v \frac{\partial v}{\partial y}+g \frac{\partial \zeta}{\partial x}+g \frac{u|V|}{C^{2} h}+a v|v|=0$

where $u$ is direction speed in $-\mathrm{x} ; v$ is direction speed in $-\mathrm{y}$ with $V$ speed at $\sqrt{v^{2}+u^{2}} ; \zeta$ is water level above the reference, $h$ is the water level depth at $\zeta+d$; and $d$ is depth below reference (m). Equation (9) shows the 2D flow momentum equation on the x-axis, where $C$ is Chezy coefficient and $a$ is roughness coefficient. Equation (10) shows the 2D flow momentum equation for the $y$-axis.

The integration of Delft3D and SOBEK was executed in the Delft-FEWS system, which is also known as JakartaFEWS. This system combines observation data of water level rainfall and weather prediction to produce water level predictions with the rainfall-runoff method. This model is specifically built for the Jakarta city flood early warning system from river overflow due to high rainfall (Ginting and Putuhena 2014).

\subsection{Coastal Inundation Modeling Design}

The modeling was carried out in the following stages:

(1) The hydrodynamic model run coupled with the wave model. The model used the following inputs: bathymetric data; direction, wind speed, air pressure, tides, and waves. The model output is the total water level and the estimated inundation area around the coast.

(2) The river model run using the Digital Elevation Model (DEM), rainfall, river water level, and river discharge data as the model input. The inundation model output estimates the inundation area, especially in the area along the river.

(3) The integration of the model outputs (1 and 2) is carried out to analyze the inundation area around the coast due to the increased as water level and river water level. At the last stage, a coastal inundation map is produced using the geographic information system technique.

The model design developed in this study aims to obtain a coastal inundation mapping, as shown in Fig. 2.

In principle, the modeling uses a coupling between the wave model and the hydrodynamic model. It incorporates tidal harmonic components integrated with the hydrological model by taking into account the inundation factor by rising river water levels. In running the model, it requires input data for several variables in the atmosphere, both from observations and predictions. The prediction that is built is

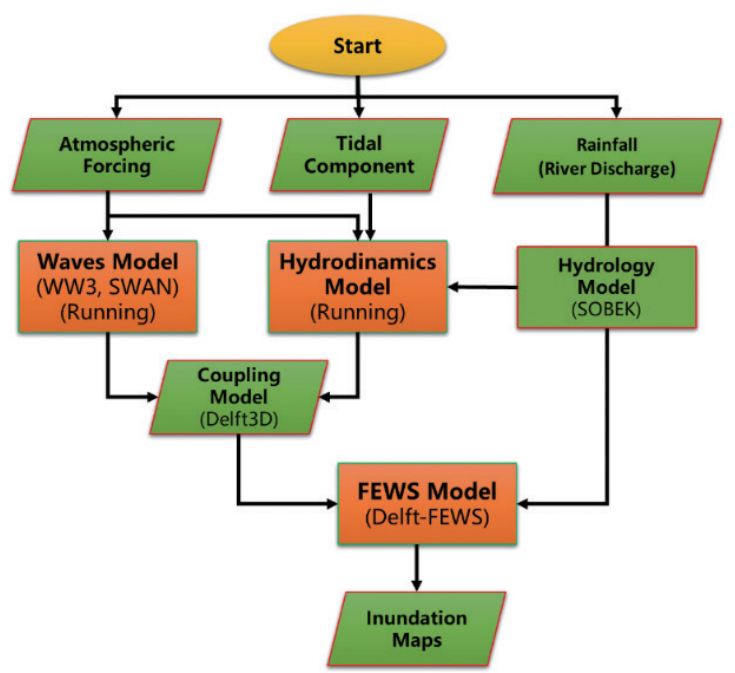

Fig. 2. Design of coastal inundation modeling and mapping. 
part of the numerical modeling approach that implements the coupling model. The model output result is the total water level, in which the astronomical and meteorological aspects are considered. The ideal coastal flood prediction also considers the inundation factor caused by the increase in the total river water level caused by an increase in rainfall. For the development of the coastal inundation model, a Flood Early Warning System (FEWS) platform was used that can integrate the prediction results from the coupling model with a river model generated by an increase in rainfall (Ginting and Putuhena 2014).

\subsection{Model Validation}

To ensure the model is accurate, before mapping the inundation, the model output results in the form of the water level are first validated quantitatively by comparing the model output to the observational data. The parameters tested are water-level height, validated with tidal observation data against the reference observation point. The validation used in this study was analysis of the coefficient of determination, Root Mean Square Error (RMSE) and Bias error (Damayanti 2011; SWAN 2011; Chang et al. 2018).

$R^{2}=\frac{\left[\sum_{i=1}^{n}\left(q_{s i}-\bar{q}_{s}\right)\left(q_{o i}-\bar{q}_{o}\right)\right]^{2}}{\sum_{i=1}^{n}\left(q_{s i}-\bar{q}_{s}\right)^{2} \sum_{i=1}^{n}\left(q_{o i}-\bar{q}_{o}\right)^{2}}$

$\operatorname{RMSE}=\left\{\frac{1}{n} \sum_{i=1}^{n}\left[H_{\text {sim }}\left(n_{i}\right)-H_{\text {obs }}\left(n_{i}\right)\right]^{2}\right\}^{1 / 2}$

$\operatorname{Bias}=\frac{\sum_{i=1}^{n}\left(q_{s i}-q_{o i}\right)}{n}$

where:

$q_{o i}=$ Observation data

$\bar{q}_{o}=$ Average of observation data $(\mathrm{m})$

$H_{\text {sim }}\left(n_{i}\right)=$ Water level based model $(\mathrm{m})$

$H_{o b s}\left(n_{i}\right)=$ Result of tidal observation (m)

$q_{s i}=$ Simulation data (i)

$q_{o i}=$ Observation data (i)

\subsection{Coastal Inundation Modeling Process}

\subsubsection{Coastal Inundation Model Design}

The detailed model design scheme developed in this study was sourced from Fig. 2, with the aim of obtaining a coastal inundation mapping, as shown in Fig. 3.

As shown Fig. 3, the system started by running a wave model using the WaveWatch III and 0.5-degree Global Forecast System (GFS) dataset in the South China Sea domain. The simulating wave nearshore (SWAN) (SWAN 2011) model was used in shallow water to simulate wind and generate waves in coastal areas and the surf-zone (Booij et al. 1999). The hydrodynamic model ran using a multidimensional simulation program that calculates waves and water levels. As mentioned earlier, this research used a Delft3D model with three domains, including the North Jakarta domain coupled with the wave model. The boundary was obtained from the tidal components over a measurement period of 1 hour from Indonesia Geospatial Information Agency (BIG). In the last stage, the outputs of the Delft3D model were integrated with the flood early warning system (FEWS) using SOBEK from J-FEWS to analyze the inundation level rise caused by increased rainfall and caused flooding.

The SOBEK model uses input data from the hourly rainfall data from the Automatic Rain Gauge (ARG) and Automatic Weather Station (AWS), which is obtained from the Meteorology, Climatology and Geophysics Agency (BMKG); hourly rainfall telemetry from ARG, obtained from the Public Works and Housing Ministry (PUPR); weather radar C-Band from the Meteorological, Climatological, and Geophysical Agency (BMKG); satellite imagery from BMKG, and Water Level Model from Center for Water Resources (PusAir). In addition, SOBEK also uses rain model prediction input from ECMWF and Weather Research Forecasting (WRF) with previous dataset input from GFS, obtained from BMKG as a comparison of the water level and river discharge results in the Delft-FEWS system. The Delft-FEWS platform is a system developed by Deltares, the functions of which are to automatically save, present, and process data and models. The J-FEWS system was developed using Delft-FEWS platform as an automatization platform and SOBEK as a hydrological-hydrodynamic model (Kasbullah and Marfai 2014).

\subsubsection{Domain Model Setup}

The first step in preparing the system was to select domains, resolution, bathymetry, and boundary value. The Jakarta coastal inundation modeling consists of three nesting domains: the South China Sea domain, the Java Sea domain, and the Jakarta domain. The nested grid model was used with the assumption that those three domains' boundary values could influence each other. This is a crucial step in determining the quality of a numerical model. This domain consisted of 147.730 cells, which means that this domain's computation was carried out according to the number of grids; the domain consisted of 374 longitudinal and 395 latitudinal grids (see Fig. 4a). A spherical grid was used as the coordinate system, considering that this scheme involves Coriolis force calculation based on the longitudinal and latitudinal coordinates.

This grid domain was developed in the RGFGRID module available on Delft3D, and each of the domain's grid were given a resolution of $9 \mathrm{~km}$. Several things were taken into considerations while determining the grid domain, such 


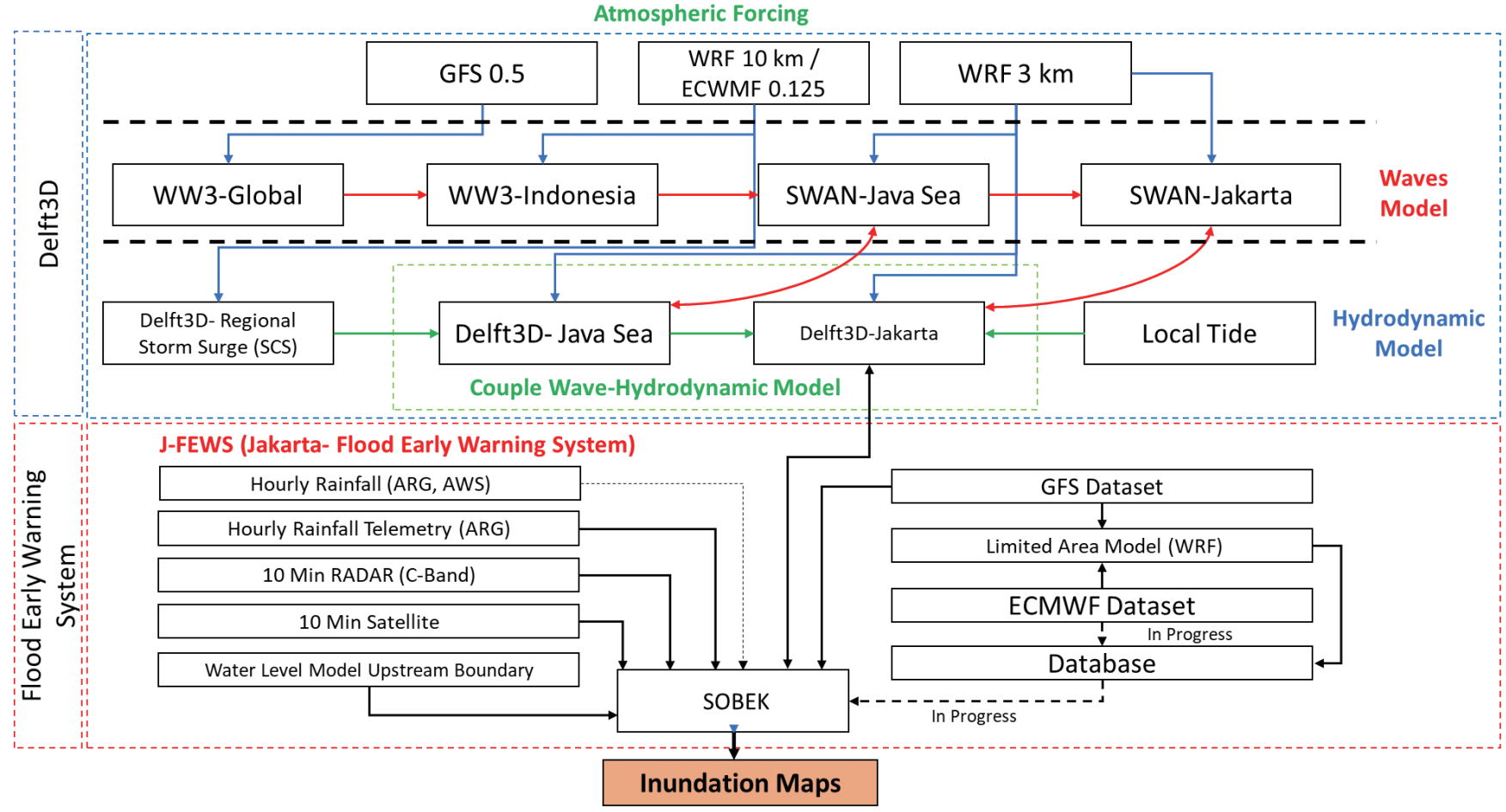

Fig. 3. Scheme of coastal inundation modeling and mapping.

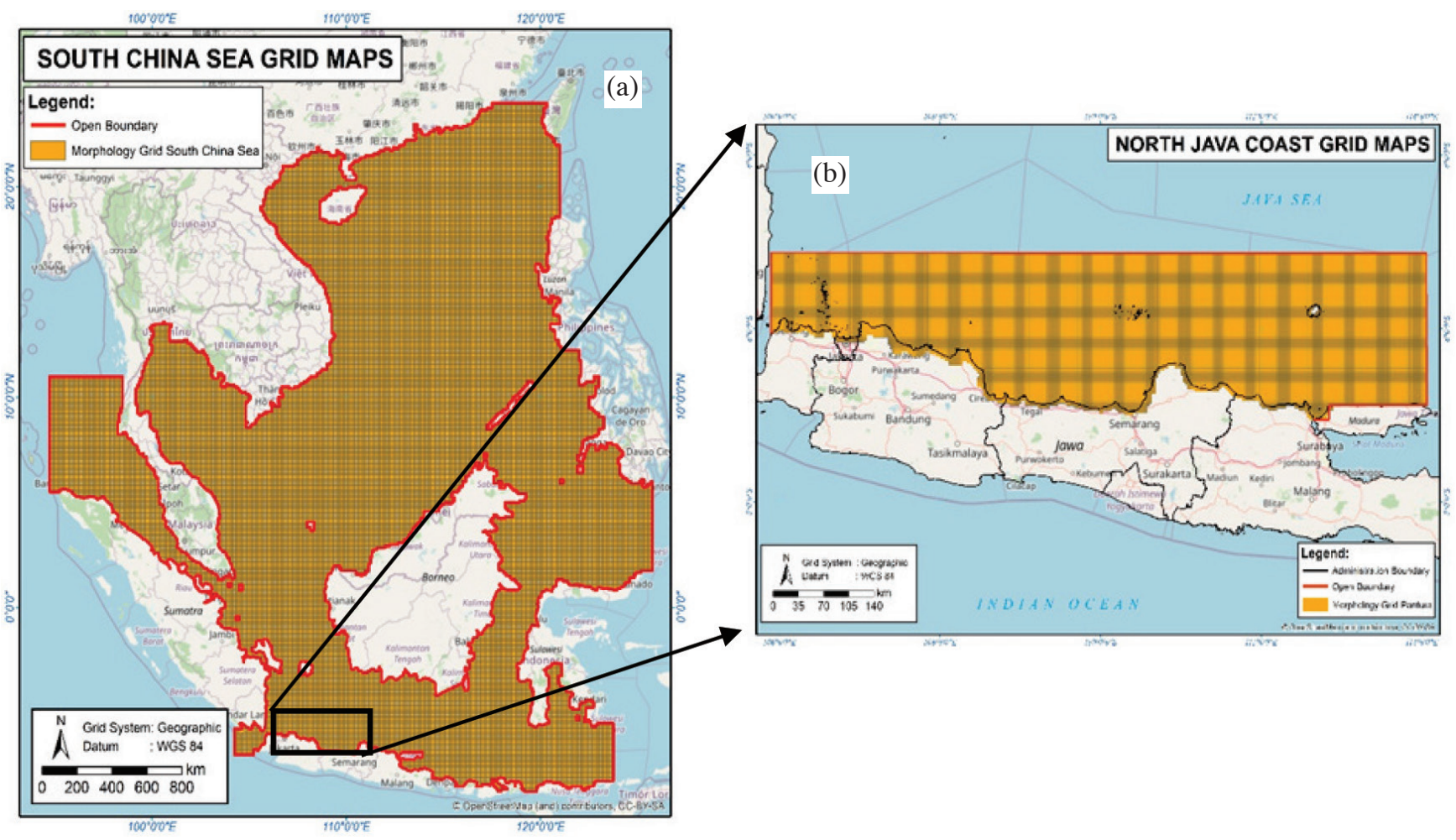

Fig. 4. (a) The South China Sea domain with open boundary values uses tidal module data consisting of $374 \times 395$ grids and (b) the Java Sea domain uses closed boundary values from coastlines and open boundary values from time-series consisting of $304 \times 73$ grids. (Basemap: Batimetri Nasional, BIG). 
as orthogonality, where $\cos (\phi)<0.02$, the angle of intersection between two grid lines, and the aspect ratio ranging from one to two. The next step was the preparation of bathymetric data. These data were considered important because they would serve as values in each grid included in the numerical calculation. We used the National Bathymetry (Batimetri Nasional or Batnas) and Rupa Bumi Indonesia (RBI) datasets published by the Geospatial Information Agency (Badan Informasi Geopasial or BIG) (Libriyono 2012). These data were obtained by processing the gravity anomaly inversion and altimetric data with acoustic data at a spatial resolution of 6-arc-second. Bathymetry in this domain was self-developed by performing triangular interpolation and internal diffusion between the previously prepared grid domain and bathymetric raw data using the QUICKIN module on Delft3D. This pre-processing step generates the bathymetric values of those $374 \times 395$ grids (see Fig. $4 a$ ). The Java Sea domain was developed using the RGFGRID module on the Delft3D, with a total of 22.192 cells consisting of 304 longitudinal and 73 latitudinal grids (see Fig. 4b). The coordinate system in the Java Sea is made up of spherical coordinates, so it calculates the Coriolis value based on latitude and longitude coordinates, although in this domain the Coriolis value is not important because it is at a latitude close to zero. The bathymetry in the Java Sea is generally shallow with a depth of 5 to $40 \mathrm{~m}$.

In North Jakarta, the grid was extended to the land surface to calculate the inundation area. The number of grids in this domain was 102.165 cells, including 417 longitudinal and 245 latitudinal grids (see Fig. 5). In the next step, the bathymetric value of each grid was obtained. Similar to the previous domain, the bathymetry in this domain was also developed using the QUICKIN module to obtain each grid's depth value. As explained before, this domain included land surface grids so that the bathymetric values in this domain could be divided into two groups, i.e., positive $(+)$ and negative (-). The bathymetry value for ocean had a positive value, while the land topography had a negative value. Elevation data were obtained from the National Digital Elevation Model (DEMNAS) developed by the BIG from several data sources, including IFSAR, TERRASAR-X, and ALOS PALSAR (Libriyono 2012).

\subsubsection{Model Setup}

Numerical simulations were calculated using tides, wind, pressure, waves, and river flows. The open boundary value uses tides as the main generator. Meanwhile, the closed boundary condition used a river mouth. Wind data were used as an atmospheric forcing in this study. Other parameters such as salinity, evaporation, current and flux were not used in this study.

The domain model's numerical configuration was determined using hydrodynamic models and wave models to calculate the influence of wind and pressure on generating water level combined with water level elevation conditions. Wind and pressure data were obtained from the European Center for Medium-Range Weather Forecast (ECMWF), accessed from the ERA-Interim reanalysis dataset (https:// www.ecmwf.int/en/forecasts/datasets/reanalysis-datasets/ era-interim). The wind and pressure data's spatial and temporal resolutions were $0.125 \times 0.125$ degrees and 6 hours, respectively as shown in Table 1 .

The tide data were obtained from the Kolinlamil Station in Jakarta Bay by considering the tidal pattern in the area (see Fig. 6). Tidal data were used in determining the boundary values for the South China Sea, Java Sea, and North Jakarta domains. Rivers, when they overflow, are very influential in increasing the inundation area in the event of a coastal flood and river discharge originates from the 13 rivers that empties into Jakarta Bay (The Wamdi Group 1988).

\subsubsection{Flood Early Warning System (FEWS)}

The influence of the rivers in relation to cpastal inundation in Jakarta cannot be understated. Figure 6 shows the rivers that empty into Jakarta Bay in North Jakarta. The Jakarta-FEWS component is useful in making coastal flood models by utilizing river discharge data from observation points of rain posts and water levels, both upstream and downstream. Figure 6 also shows the observation points used in the model's construction, namely rain gauge station, water level station, the weather radar and the tide gauge station of Kolinlamil.

The rivers in Jakarta play an important role in influencing coastal inundation. The details of the rivers are shown in Table 2.

River flow data in hydrological modeling is used to transform rain data into runoff data. The modeling concept used is known as Sacramento. The Sacramento model is a lumped model that change rain data to runoff data conceptually based on an empirical equation algorithm (Putuhena and Ginting 2013). It can be seen in Fig. 7 that the Sacramento scheme begins with the hydrological rainfall runoff module (RR), which is used to transform rain data into runoff data in each sub-district accompanied by flow propagation to the river using the Muskingum method. This method is used for the transformation from rain data to river discharge. The Muskingum method is a hydrological flow routing model with lumped parameters, which describes the transformation of discharge in a riverbed using two equations. The first is the continuity equation (conservation of mass) and the second is the relationship between the storage, inflow, and outflow of the reach (the discharge storage equation). The one-dimensional hydraulic module (1D) was used to calculate 1D flow through the main river and macro channels. Finally, the two-dimensional hydraulic module (2D) was to calculate the flood inundation area when overtopping. 
On processing of FEWS stage, the hydrodynamic model transmits water-level data to the hydraulic model, which is used as the boundary value in the downstream river model. Then, the hydraulic model returns river-level data (discharge) to the hydrodynamic model used in the model's physical process (see Fig. 8). The water level obtained from the hydrodynamic model is then transmitted to the J-FEWS to generate an inundation map.

Figure 8 presents the mechanism of data exchange between the hydrodynamic, hydraulic, and flood models. Technically, the J-FEWS system can collect the data required for the inundation early warning process and run the hydraulic model to predict floods. The J-FEWS system collects data in the form of rain observation (telemetry, radar, and satellite), rainfall prediction (model and Numerical Weather Prediction), and water level (see Fig. 3). Observed and predicted rain data are required as input for the execution of the hydrological-hydrodynamic model to predict inundation. The rains are then calculated as water discharge entering a river. Moreover, the process requires data on upstream and downstream water elevations to establish the boundary conditions (see Fig. 8). Currently, the FEWS uses the astronomical water level as its downstream boundary condition. The astronomical water level eliminates sea level anomalies resulting from atmospheric conditions. This elimination process can be further improved using a hydrodynamic prediction model.

\section{RESULTS AND DISCUSSION}

\subsection{Coupling Wave-Hydrodynamic and Hydrology}

The initial process in Fig. 3 shows the result of wave model, which produces the wave conditions on 5 December 2017 can be seen in Fig. 9. This figure shows that the wind affects the height of the waves in Jakarta Bay, the eastern part of the Java Sea, spreading to the west. This is comparable to the wind conditions during the transition to the rainy season (monsoon), which have a relatively strong westerly wind pattern (Chu et al. 2004). This process significantly increases the wave height in Jakarta Bay and can propagate up to the coastal area. In some instances, in maximum tide conditions, the waves can become very high even though they were formed in shallow waters. This factor can increase the risk of inundation in coastal areas.

The water level in Jakarta Bay is shown in Fig. 10 as the result of hydrodynamic model (Fig. 3); The water level in the coastal area tends to be higher than in the high seas. The coastal area saw an increase in water level of around 0.66 to $0.68 \mathrm{~m}$. This was caused by the supermoon phenomenon between 3 to 5 December 2017, which raised the water level.

It can be seen in Fig. 10 that at 03.00 UTC, there was coastal inundation in some parts of North Jakarta. The peak of the coastal inundation is also related to the maximum tide phase at the beginning of the month during the supermoon. On the basis of the modeling results, Figs. 9 and 10 show a relationship with the resulting physical coupling. The effect of rising water levels caused by the supermoon phenomenon leads to wave heights and strong winds, better known as surge. However, the argument presented in this study is that the effect of waves caused by wind is not very significant in terms of influence on the total water level, it is the supermoon phenomenon that causes the maximum tide, which more significantly affects the total water level. Figure 10

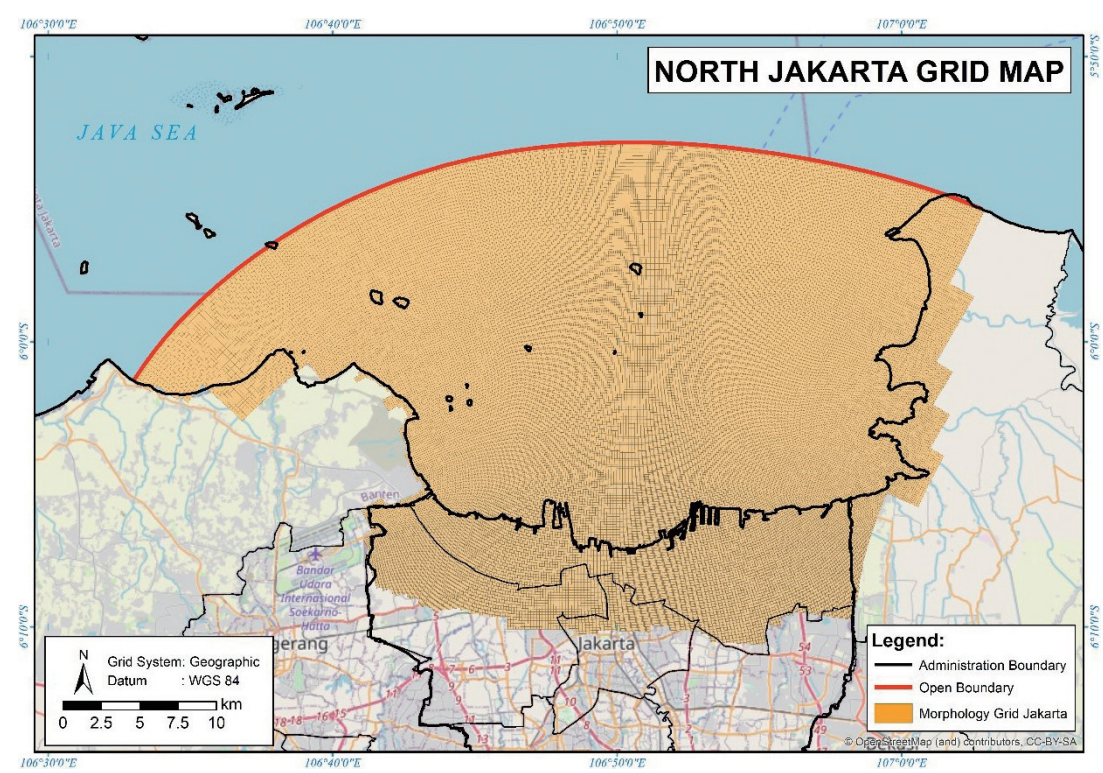

Fig. 5. The North Jakarta domain with a resolution of $1 \mathrm{~km}$, the open boundary value uses the influence of the Java Sea domain, and the closed boundary uses the coastline and Shuttle Radar Topography Mission (SRTM). (Basemap: Batimetri Nasional, BIG). 
Table 1. Input parameters for the model domain.

\begin{tabular}{c|c|ccc}
\hline \multirow{2}{*}{ No } & \multirow{2}{*}{ Parameters } & \multicolumn{3}{|c}{ Domain Configuration } \\
\cline { 3 - 5 } & & Domain 1 (South China Sea) & Domain 2 (Java Sea) & Domain 3 (North Jakarta) \\
\hline 1 & Time Step & 5 minutes & 5 minutes & 1 minute \\
2 & Physics & Wind $\left(\mathrm{m} \mathrm{s}^{-1}\right)$ & Wind $\left(\mathrm{m} \mathrm{s}^{-1}\right)$ & Wind $\left(\mathrm{m} \mathrm{s}^{-1}\right)$ \\
3 & Boundary & Tide & Wave $(\mathrm{m})$ & Tide and Wave \\
4 & Wind input $\left(\mathrm{m} \mathrm{s}^{-1}\right)$ & ECMWF reanalysis & ECMWF reanalysis & ECMWF reanalysis \\
5 & Pressure input $(\mathrm{mb})$ & ECMWF reanalysis & ECMWF reanalysis & ECMWF reanalysis \\
6 & Discharge model & - & - & SOBEK \\
7 & Wave model & - & WW3-SWAN & SWAN \\
8 & Hydrodynamic model & Delft3D & Delft3D & Delft3D \\
9 & Forces & - & Dissipation 3D & Dissipation 3D \\
10 & Bottom friction & - & JONSWAP $\left(0.038 \mathrm{~m}^{2} \mathrm{~s}^{-3}\right)$ & JONSWAP $\left(0.038 \mathrm{~m}^{2} \mathrm{~s}^{-3}\right)$ \\
11 & Whitecapping & - & Komen et al. 1994 & Komen et al. 1994 \\
12 & Computational & - & Non-stationary & Non-stationary \\
13 & Coupling interval & 30 minutes & 30 minutes & 30 minutes \\
\hline
\end{tabular}

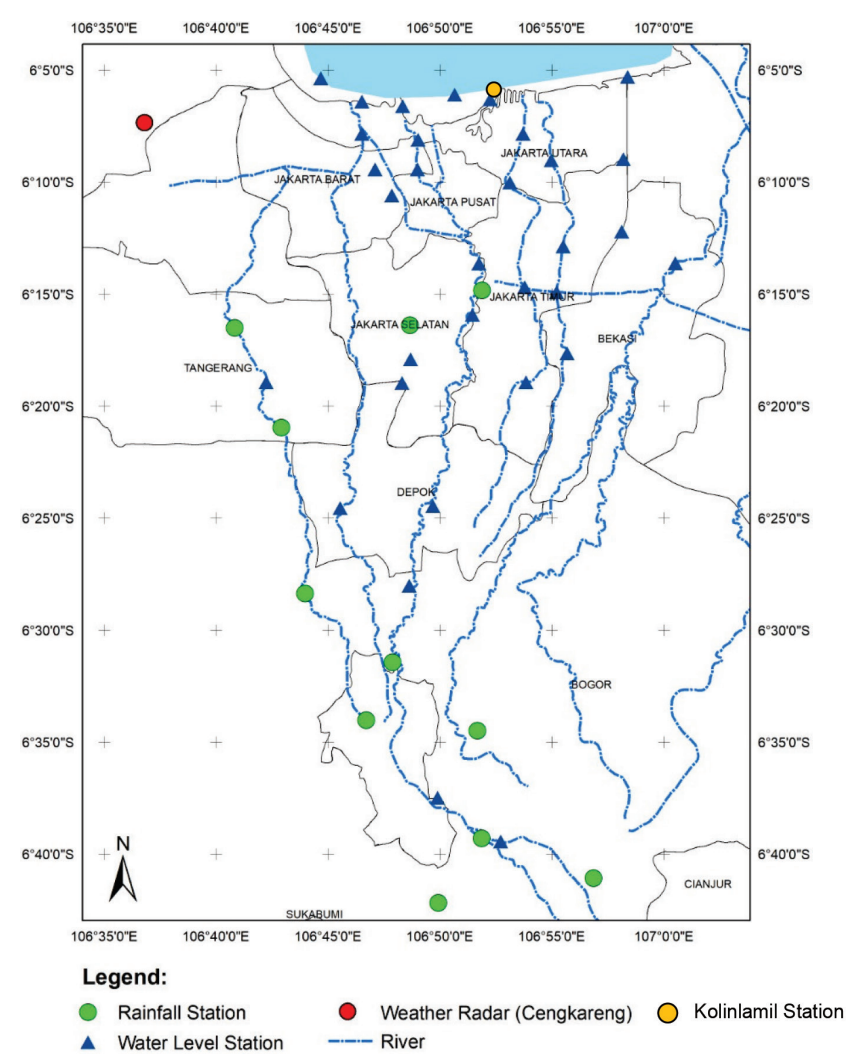

Fig. 6. Map of the rivers and observation stations in Jakarta. (Source: BMKG, PusAir, Pushidros AL, and Rupa Bumi Indonesia/BIG). 
Table 2. Rivers in Jakarta.

\begin{tabular}{c|ccc|c}
\hline No & Name of river & & No & Name of river \\
\hline 1 & Mookevaart & & 8 & Baru Timur \\
2 & Angke & & 9 & Cipinang \\
3 & Pesanggrahan & & 10 & Sunter \\
4 & Krukut & & 11 & Buaran \\
5 & Grogol & & 12 & Jati Kramat \\
6 & Baru Barat & & 13 & Cakung \\
7 & Ciliwung & & \\
\hline
\end{tabular}

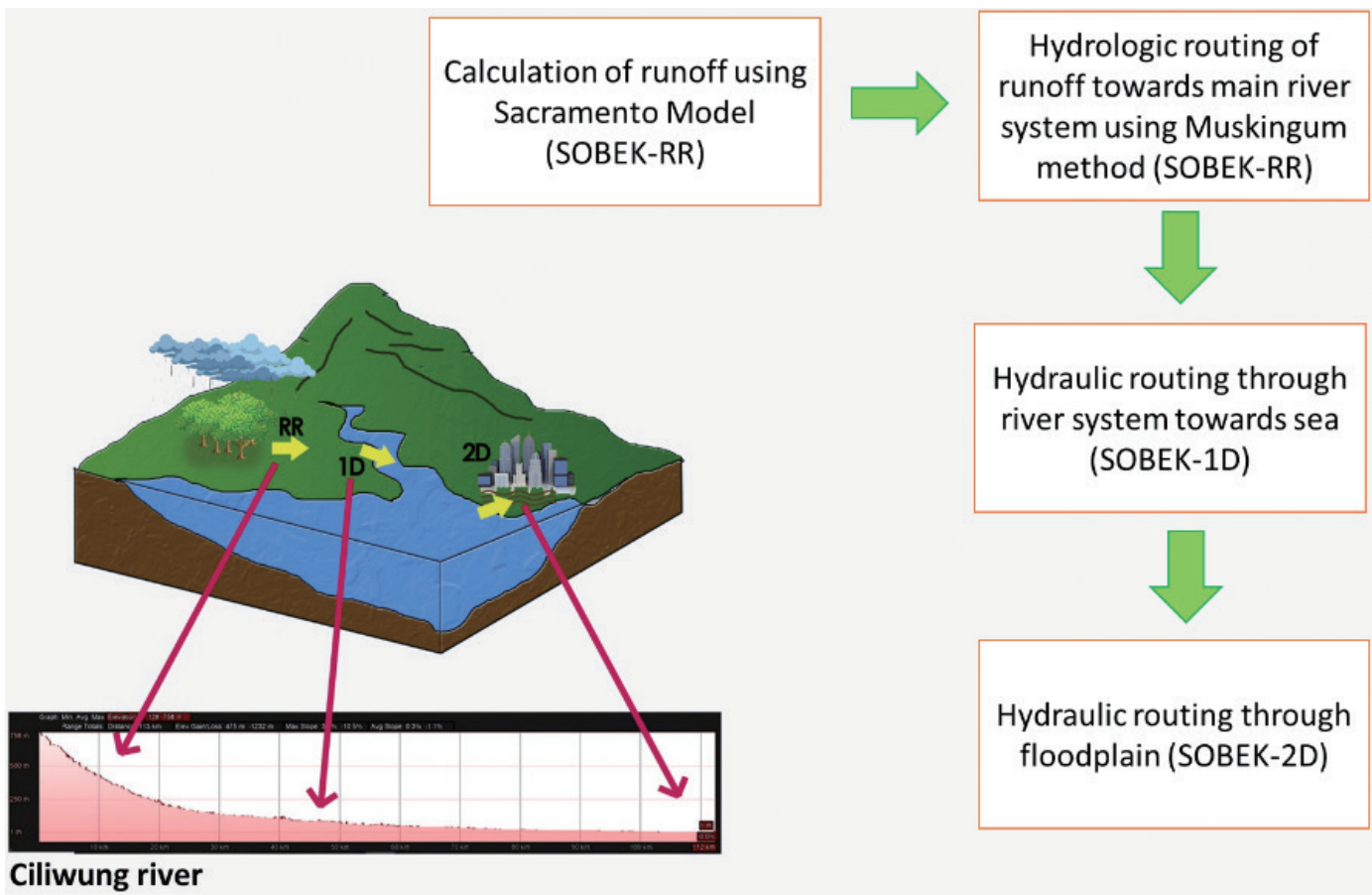

Fig. 7. Hydrology Model Scheme for Jakarta Flooding (Marfai 2013).

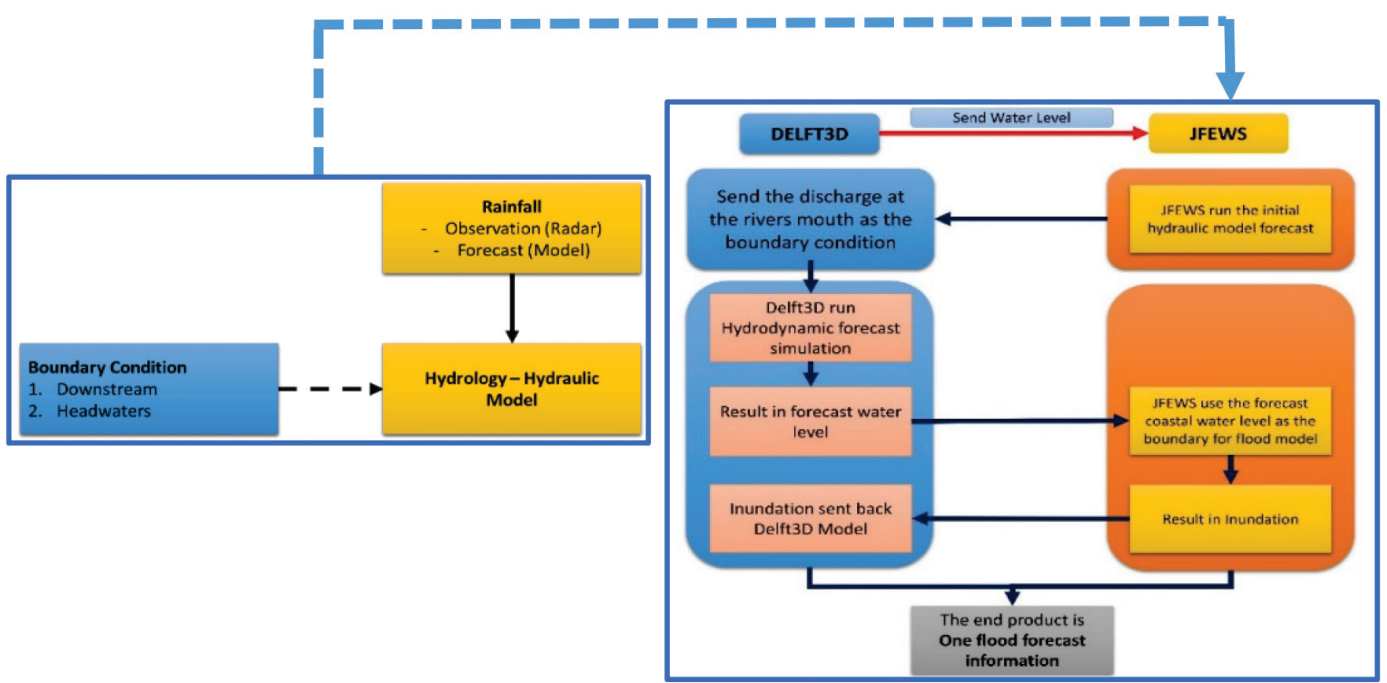

Fig. 8. Integration scheme of the coastal inundation model. 


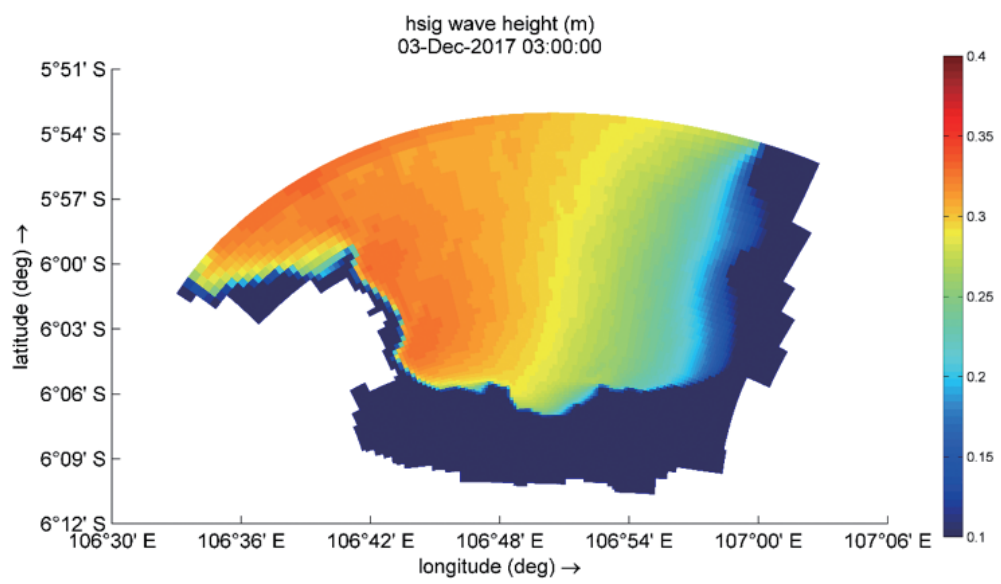

Fig. 9. Wave height on 5 December 2017 in Jakarta Bay.

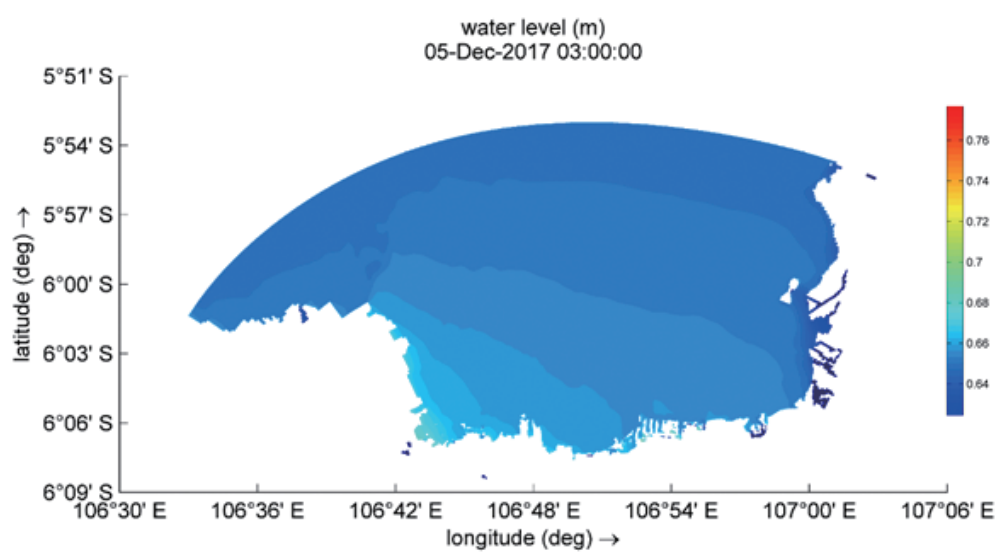

Fig. 10. Water level on 5 December 2017 in Jakarta Bay.

shows that the total water level is was higher in the coastal area of North Jakarta.

\subsection{Validation of Water Level}

The water level from the model was validated using the observation data from BIG and Indonesian Navy Hydrographic and Oceanographic Center (Pusat Hidrografi Angkatan Laut-Pushidros AL). Pushidros AL is a hydrographic agency under the control of the Indonesian Navy that provides annual tidal prediction data services for the Indonesian seas based on astronomical factors. Jakarta has a diurnal characteristic, with one high tide and one low tide per day. Maximum tides occurred on 4 and 5 December 2017, as shown in Fig. 11. The highest tide occurred on 5 December 2017, at $2.31 \mathrm{~m}$, while the lowest occurred on 4 December 2017, at $1.03 \mathrm{~m}$. From 30 November to 8 December 2017, the tidal pattern was marked by rising water levels, followed by low water levels, at varying heights. All this coincided with the full moon when the Earth is located exactly between the sun and the moon, forming a straight line. The full-moon phase appeared on the 14th day, coinciding with the moon phase occurring on 3 December 2017. The supermoon phase causes spring tides characterized by a series of massive tides and small tides (Poerbondono and Djunarsjah 2005).

Compared with the phenomena during the peak of the supermoon on 3 December 2017, there was a shift in the occurrence of the highest high tide with a lag of approximately 2 to 3 days. Our observation data have characteristics similar to those identified by L.H.N.C. (1962), i.e., the tidal pattern in Jakarta Bay was of the diurnal type, which is influenced by solar phenomena with one high tide and one low tide. Specifically, a supermoon can be a full moon or a new moon, whose distance is $10 \%$, or less, of its closest approach to the Earth. When this phenomenon occurs, the moon looks bigger and brighter, even though the shift is only a few kilometers. According to astronomy, the moon may be located at its farthest or nearest point from the Earth. This farthest point is called the apogee, while the nearest point is called the perigee. When the moon reaches the perigee, the supermoon phenomenon occurs (NOAA 2020). As 


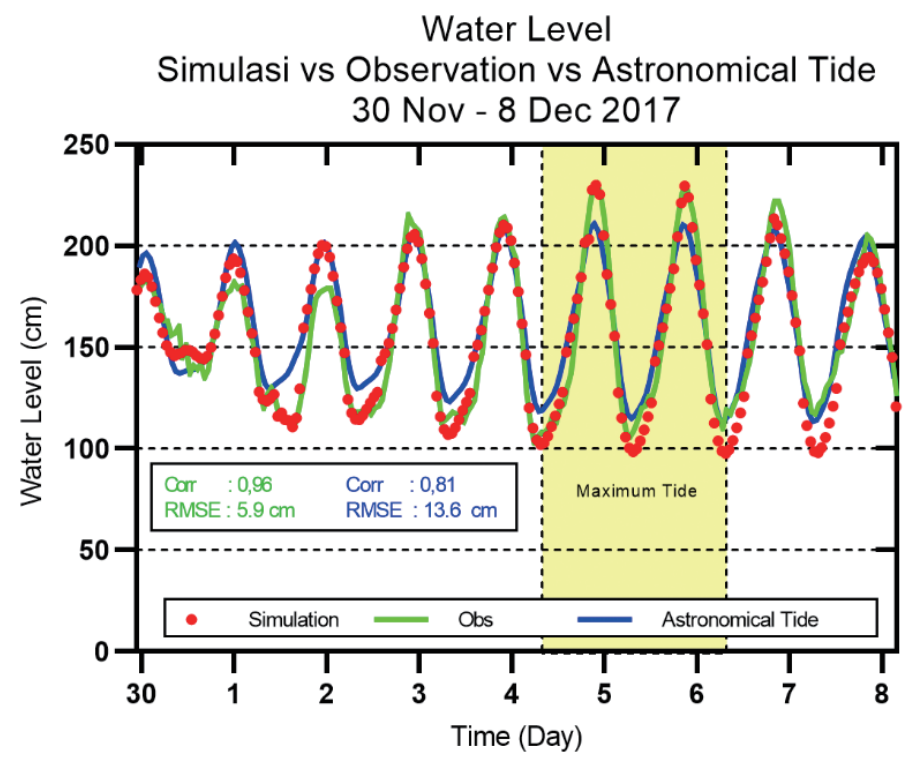

Fig. 11. Comparison of the Water Level results from the Delft3D model with observation data and astronomical tide from 30 November to 8 December 2017.

a result of its proximity, the moon exerts its influence on the Earth, such as generating tidal waves through the force of gravity, which becomes stronger on such occasions. Thus, supermoons cause higher tides than the full moon, because that is when the moon is closest to the Earth (Alfonso-Sosa 2016). The supermoon can also increase the potential for coastal inundation.

According to Fig. 11, there is a fluctuation in the resulting pattern. The tide that occurred during our case study belonged to the extra-high spring tides category and had the potential to inundate the land surface. The maximum water level value on 30 November 2017, in the simulation was $1.82 \mathrm{~m}$ and the observed value was $1.83 \mathrm{~m}$. On 1 December 2017 , the maximum simulated water level value was $1.89 \mathrm{~m}$ and the observed value was $1.82 \mathrm{~m}$. On 2 December 2017, the maximum simulated water level value was $1.96 \mathrm{~m}$ and the observed value was $1.85 \mathrm{~m}$. On 3 December 2017, the maximum the simulated water level value was $2.03 \mathrm{~m}$ and the observed value is $2.15 \mathrm{~m}$. On 4 December 2017, the maximum simulated water level value was $2.07 \mathrm{~m}$ and the observed value was $2.14 \mathrm{~m}$. On 5 December 2017, the highest simulated water level value was $2.08 \mathrm{~m}$ and the observed value is $2.31 \mathrm{~m}$. On 6 December 2017, the highest simulated water level value was $2.05 \mathrm{~m}$ and the observed value was $2.30 \mathrm{~m}$. On 7 December 2017, the highest simulated water level value was $2.00 \mathrm{~m}$ and the observed value was $2.22 \mathrm{~m}$.

On 8 December 2017, the highest simulated water level value was $1.92 \mathrm{~m}$ and the observed value was $2.05 \mathrm{~m}$. A comparison between the simulation and observation shows that the correlation value is 0.96 , and the RMSE value is $5.9 \mathrm{~cm}$ or $0.059 \mathrm{~m}$ with a bias of $6.0 \mathrm{~cm}$ (see Fig. 12a). However, the comparison of the simulations and astronomi- cal tides from Pushidros AL shows a correlation value of 0.81 , and an RMSE of $13.6 \mathrm{~cm}$ or $0.136 \mathrm{~cm}$ with a bias of $13.8 \mathrm{~cm}$ (see Fig. 12b). From the results of these comparisons, it can be seen that the developed model is better than research that only takes into account the influence of the atmosphere and hydrodynamics in the local domain (Yahya Surya et al. 2019). This can be seen in the mapping results of Fig. 13, in which the influence of the atmosphere and hydrodynamics of the regional domain, namely the South China Sea and Java Sea are calculated.

\subsection{Coastal Inundation Mapping}

This coastal inundation model used a geographic information system (GIS) to overlay several parameters that can cause flooding. In this study, the simulation involved topography parameters, distance from the coast, and distance from the river. The simulation will produce more in-depth information if other factors causing floods are included. Information about topographical elevation was obtained from the Shuttle Radar Topography Mission (SRTM) image data at a spatial resolution of $90 \mathrm{~m}$ (Jarvis et al. 2008). These images present DEM information recorded using a remote sensing system that utilizes the microwave wavelength from the electromagnetic wave spectrum. The elevation data obtained from the SRTM are digital surface model (DSM) information. The DSM generates information about the elevation of the location and any objects on the land surface, such as vegetation and human settlements. Information about an area's topographical elevation will have a significant influence on the use of each datum. The smallest unit's spatial resolution in an area that can be recorded by a remote 

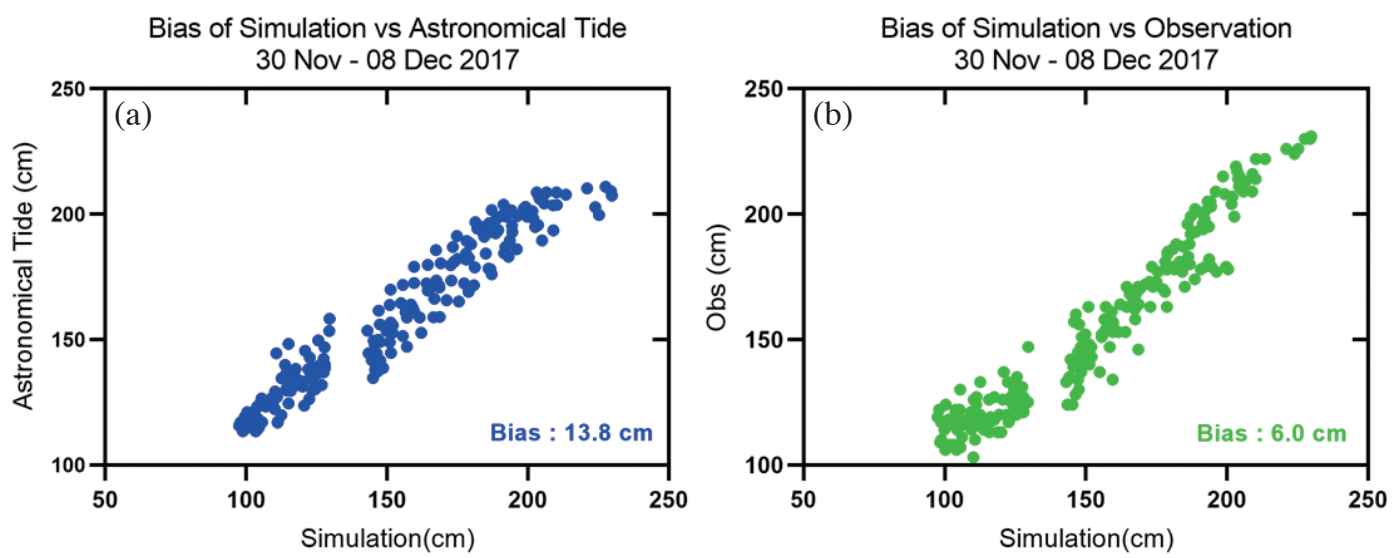

Fig. 12. Bias value of (a) the Comparison between the simulation and astronomical tide from Pushidros AL and (b) the Comparison between the simulation and observed tide data at Kolinlamil station.

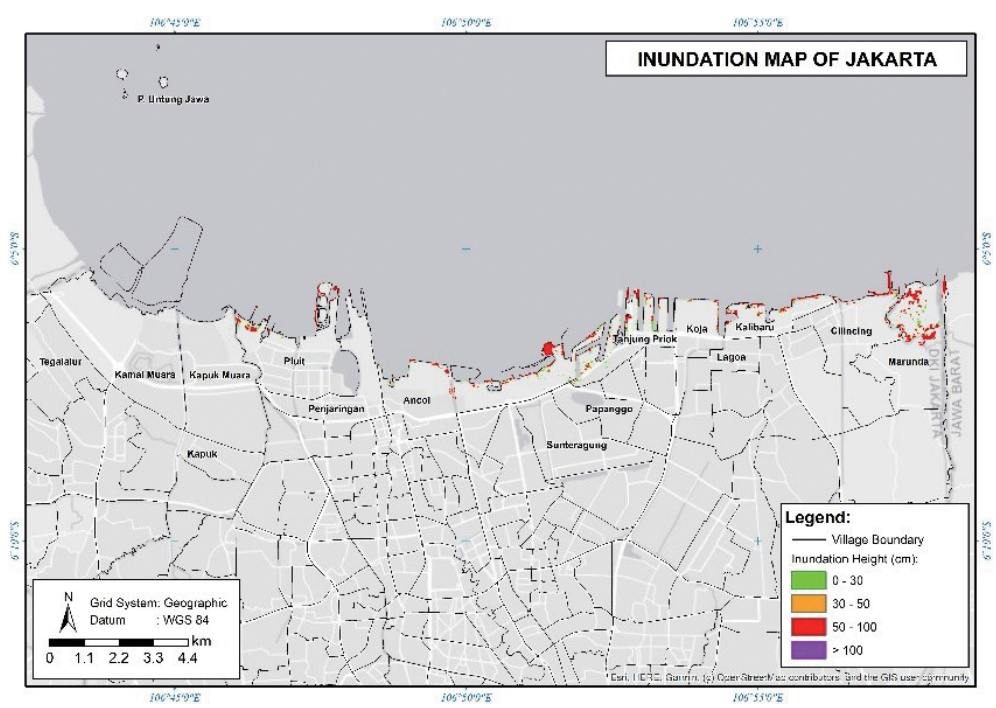

Fig. 13. Resulting Map of coastal inundation in North Jakarta. (Basemap: Rupa Bumi Indonesia, BIG).

sensing system using SRTM images consists of $30 \mathrm{~m}, 90 \mathrm{~m}$, and $1 \mathrm{~km}$. The scope of the area recorded by SRTM images covers the entire world, including Indonesia. There are two types of DEMs - digital surface model (DSM) and digital terrain model (DTM) (Yahya Surya et al. 2019).

Flood modeling requires the surface elevation related to the elevation boundary of inundated areas (López-Dóriga and Jiménez 2020) (see Fig. 13). The simulation starts with the production of elevation information by the SRTM topographical map, followed by a query generation, i.e., the retrieval of elevation data for a particular scenario. If the scenario involves a maximum tidal level of $1 \mathrm{~m}$, it is logical that all land areas lower than $1 \mathrm{~m}$ will be inundated. These areas will be automatically formed with the assistance of GIS software. Furthermore, the areas known to have an elevation of less than $1 \mathrm{~m}$ are reviewed with other parameters, such as the generalization using distance parameters from the coast and rivers. Areas with the most significant risk of experiencing tidal flooding are those nearest to the coastline and rivers debouching into the ocean. The DEM use in this study was using the Land use of 2013 data which was updated using Landuse data from Google Earth of 2017. Coastline areas have a risk boundary of up to $1 \mathrm{~km}$ from the shoreline, whereas rivers have a risk boundary of up to $400 \mathrm{~m}$ from the riverbank. These areas, which result from the overlaying of each parameter that can cause flooding with administrative boundaries, are the areas predicted to be the focus of early warning systems. The integration of the SOBEK model, atmospheric data, and tidal observation data resulted in a more accurate inundation model.

The mapping of inundation areas in North Jakarta based on the Delft-FEWS platform output shows that North Jakarta experiences inundation in several areas (see Fig. 13 and Table 3). 
Table 3. Area affected by coastal inundation in North Jakarta during the maximum tide on 5 December 2017.

\begin{tabular}{c|ccc|c}
\hline \multirow{2}{*}{ Subdistrict } & \multicolumn{3}{|c|}{ Domain Configuration } & \multirow{2}{*}{ Areas $\left(\mathbf{m}^{2}\right)$} \\
\cline { 2 - 4 } & $\mathbf{0 - 3 0} \mathbf{~ c m}$ & $\mathbf{3 0}-\mathbf{5 0} \mathbf{~ c m}$ & $\mathbf{5 0 - 1 0 0 ~ c m}$ & \\
\hline Ancol & $\mathbf{7 2 . 3 9 2 3 6}$ & $\mathbf{3 5 . 1 0 0 4 3}$ & $\mathbf{2 8 0 . 5 5 0 8 0}$ & $\mathbf{3 8 8 . 0 4 3 5 8}$ \\
Cilincing & 19.24013 & 11.65576 & 119.05824 & 149.95413 \\
Kalibaru & $\mathbf{3 6 . 5 2 1 5 0}$ & $\mathbf{2 5 . 4 7 2 5 6}$ & $\mathbf{1 0 7 . 1 8 2 5 0}$ & $\mathbf{1 6 9 . 1 7 6 5 6}$ \\
Koja & 9.96763 & 6.79024 & 20.58675 & 37.34462 \\
Marunda & $\mathbf{5 3 . 7 9 9 8 8}$ & $\mathbf{2 7 . 7 5 4 0 8}$ & $\mathbf{3 7 4 . 4 8 2 5 7}$ & $\mathbf{4 5 6 . 0 3 6 5 3}$ \\
Pluit & 35.59675 & 24.95231 & 133.02573 & 193.57478 \\
Tanjung Priok & $\mathbf{8 7 . 9 8 3 1 0}$ & $\mathbf{4 2 . 4 2 0 1 1}$ & $\mathbf{1 4 1 . 7 6 9 9 1}$ & $\mathbf{2 7 2 . 1 7 3 1 2}$ \\
Area $\left(\mathrm{m}^{2}\right)$ & 21.37395 & 14.64553 & 70.70446 & 1666.30332 \\
\hline
\end{tabular}

Figure 13 and Table 3 show the coastal inundation conditions on 5 December 2017, with water levels ranging from 50 to $100 \mathrm{~cm}$ in the Ancol subdistrict area. In Kalibaru subdistrict, the water level ranged from 50 to $100 \mathrm{~cm}$, and in some areas, there was coastal inundation with water levels ranging from 0 to $30 \mathrm{~cm}$. The worst affected areas were in the north, which are directly adjacent to the coastal area. The total inundation areas in the two subdistricts were 388.04358 and $169.17656 \mathrm{~m}^{2}$, respectively.

In Marunda subdistrict, the coastal inundation conditions ranged from 50 to $100 \mathrm{~cm}$ in height. The areas were predominantly near the riverbanks. The most dominant coastal inundation height is indicated by a red contour, namely, a height of 50 to $100 \mathrm{~cm}$. The coastal inundation with a water height range of 0 to $30 \mathrm{~cm}$ only occured in a small area in the north-central region. The total inundation area in Marunda subdistrict was $456.03653 \mathrm{~m}^{2}$. This is possibly because the area is higher than the surrounding area. This is related to land subsidence in North Jakarta, as described the study of Takagi et al. (2016). Furthermore, the Tanjung Priok subdistrict shows that the water level during coastal inundation ranged from 50 to $100 \mathrm{~cm}$, and in the western area, it ranged from 0 to $30 \mathrm{~cm}$. The total inundation area in Tanjung Priuk subdistrict was $272.17312 \mathrm{~m}^{2}$.

Inundation areas in the four sub-districts had an average inundation level of 50 to $100 \mathrm{~cm}$, while some other areas had an average inundation level of 0 to $30 \mathrm{~cm}$. An average inundation of 50 to $100 \mathrm{~cm}$ was seen in the areas almost directly adjacent to the coast of North Jakarta, which caused maximum tidal interactions with the topographic elevation of the land.

\section{CONCLUSION}

In this research, a coastal inundation model and mapping was simulated by considering the atmosphere and oceanography components by integrating wave models, hydrodynamic models, and river or hydrological models. On the basis of observational data used during the case study from 30 November to 5 December 2017, the maximum tide in Jakarta Bay from 3 to 5 December 2017 increased the potential for inundation in the nearby land area. The effect of the supermoon phenomenon also exacerbated this during the maximum tide.

The results of the wave-hydrodynamic model demonstrated a relationship between the two. However, the water level is more significant in affecting the rising water levels around the coastal area. The comparison between the coastal inundation model results and the water level observation data resulted in a correlation value of 0.96, an RMSE value of $5.29 \mathrm{~cm}$, and a bias value of $6.0 \mathrm{~cm}$, which demonstrates that the results of the model matched with the observations. In contrast, comparing the model with the astronomical tide gave a correlation of 0.81 , an RMSE value of $13.6 \mathrm{~cm}$, and a bias value of $13.6 \mathrm{~cm}$. Thus, it appears that the model results are better than Pushidros AL's predictions, which only consider astronomical factors to determine the water level.

The coastal inundation mapping shows that the highest levels of maximum tide generated by the system range from 50 to $100 \mathrm{~cm}$, and from 0 to $30 \mathrm{~cm}$ in other cases. The maximum inundation at a level of 50 to $100 \mathrm{~cm}$ occurred in several areas in North Jakarta, such as the Tanjung Priok and Marunda subdistricts with the total inundation area of 272.17312 and $456.03653 \mathrm{~m}^{2}$, respectively. In comparison, the maximum inundation occurred in the Ancol and Kalibaru subdistricts, at the level of 0 to $30 \mathrm{~cm}$ for the total inundation area of 388.04358 and $169.17656 \mathrm{~m}^{2}$, respectively. The result showed that this model is more accurate in terms of giving information on coastal inundation as part of an early warning system for coastal disasters, which should be used to mitigate the risk of coastal disasters in North Jakarta.

\section{REFERENCES}

Alfonso-Sosa, E., 2016: Perigean Spring Tides versus Apogean Spring Tides and their Implication in Pelagic 
Mixing in the Next 1.4 Billion Years. Ocean Physics Education in Puerto Rico, 33 pp, doi: 10.13140/ RG.2.2.17006.20802. [Link]

Bappenas, 2007: Report on Estimation of Damage and Losses Post Flood Disaster Early February 2007 In the Greater Jakarta Area (Jakarta, Bogor, Depok, Tangerang, and Bekasi), Indonesian Ministry of National Development Planning/BAPPENAS, Jakarta, Indonesia.

Booij, N., R. C. Ris, and L. H. Holthuijsen, 1999: A thirdgeneration wave model for coastal regions: 1 . Model description and validation. J. Geophys. Res., 104, 7649-7666, doi: 10.1029/98JC02622. [Link]

Chang, C.-H., M.-K. Chung, S.-Y. Yang, C.-T. Hsu, and S.-J. Wu, 2018: A Case Study for the Application of an Operational Two-Dimensional Real-Time Flooding Forecasting System and Smart Water Level Gauges on Roads in Tainan City, Taiwan. Water, 10, 574, doi: 10.3390/w10050574. [Link]

Chaussard, E., F. Amelung, H. Abidin, and S.-H. Hong, 2013: Sinking cities in Indonesia: ALOS PALSAR detects rapid subsidence due to groundwater and gas extraction. Remote Sens. Environ., 128, 150-161, doi: 10.1016/j.rse.2012.10.015. [Link]

Chu, P. C., Y. Qi, Y. Chen, P. Shi, and Q. Mao, 2004: South China Sea Wind-Wave Characteristics. Part I: Validation of Wavewatch-III Using TOPEX/Poseidon Data. J. Atmos. Ocean. Technol., 21, 1718-1733, doi: 10.1175/JTECH1661.1. [Link]

Damayanti, F., 2011: Hydrodynamic Modeling for Flood Hazard Assessment in Telomoyo Catchment, Central Java, Indonesia. Master Thesis, Gadjah Mada University and Faculty of Geo-information Science and Earth Observation, University of Twente, The Netherlands, $85 \mathrm{pp}$.

De Alencar, N. M. P., M. Le Tissier, S. K. Paterson, and A. Newton, 2020: Circles of Coastal Sustainability: A Framework for Coastal Management. Sustainability, 12, 4886, doi: 10.3390/su12124886. [Link]

Deltares, 2010: Hydrodynamics, Rainfall Runoff and Real Time Control, User Manual, Deltares, Delft.

Ericson, J. P., C. J. Vörösmarty, S. L. Dingman, L. G. Ward, and M. Meybeck, 2006: Effective sea-level rise and deltas: Causes of change and human dimension implications. Global Planet. Change, 50, 63-82, doi: 10.1016/j.gloplacha.2005.07.004. [Link]

Farhan, A. R. and S. Lim, 2010: Integrated coastal zone management towards Indonesia global ocean observing system (INA-GOOS): Review and recommendation. Ocean Coast. Manag., 53, 421-427, doi: 10.1016/j.ocecoaman.2010.06.015. [Link]

Ginting, S. and W. Putuhena, 2014: Jakarta Flood Early Warning System. Indonesia Journal of Water Resources, 10, 71-84.
Hervouet, J. and L. Van Haren, 1996: Recent advances in numerical methods for fluid flows. In Anderson, M. G., D. E. Walling, and P. D. Bates (Eds.), Floodplain Processes, John Wiley and Sons, New York, 183-214.

IPCC, 2007: Summary for Policymakers. In: Parry, M. L., O. F. Canziani, J. P. Palutikof, P. J. van der Linden, and C. E. Hanson (Eds.), Climate Change 2007: Impacts, Adaptation and Vulnerability, Contribution of Working Group II to The Fourth Assessment Report of The Intergovernmental Panel on Climate Change, Cambridge University Press, Cambridge, UK, 7-22. Available at https://pubs.giss.nasa.gov/abs/ip01000b. html.

Jarvis, A., E. Guevara, H. I. Reuter, and A. D. Nelson, 2008: Hole-filled SRTM for the Globe: Version 4: Data Grid, CGIAR Consortium for Spatial Information. Available at http://srtm.csi.cgiar.org.

Kasbullah, A. A. and M. A. Marfai, 2014: Pemodelan Spasial Genangan Banjir Rob dan Penilaian Potensi Kerugian pada Lahan Pertanian Sawah Padi Studi Kasus Wilayah Pesisir Kabupaten Pekalongan Jawa Tengah. Geoedukasi, 3, 83-91.

Komen, G. L., L. Cavaleri, M. Donelan, K. Hasselmann, S. Hasselmann, and P. A. E. M. Janssen, 1994: Dynamics and Modelling of Ocean Waves, Cambridge University Press, Cambridge, 532 pp, doi: 10.1017/ CBO9780511628955. [Link]

L.H.N.C., 1962: Physical Oceanography By Albert Defant Pergamon Press, London, 1961. Vol. 1, pp. xvi + 729; Vol. 2, pp. viii + 598. J. Mar. Biol. Assoc. U.K., 42, 468-468, doi: 10.1017/S0025315400070089. [Link]

Libriyono, A., 2012: Sistem Informasi Geospasial Batimetri Nasional Berbasis Web. Lokakarya Integrasi Data dan Informasi Geospasial Kelautan Nasional guna Mendukung MP3EI, doi: 10.13140/RG.2.2.15067.05921. [Link]

López-Dóriga, U. and J. A. Jiménez, 2020: Impact of Relative Sea-Level Rise on Low-Lying Coastal Areas of Catalonia, NW Mediterranean, Spain. Water, 12, 3252, doi: 10.3390/w12113252. [Link]

Marfai, M. A., 2013: Bencana Banjir Rob: Studi Pendahuluan Banjir Pesisir Jakarta, Edition 1, Graha Ilmu, Yogyakarta, $78 \mathrm{pp}$.

NASA, 2017: A Supermoon Trilogy. Available at https:// science.nasa.gov/science-news/news-articles/a-supermoon-trilogy. (Accessed on 01 January 2021)

Nicholls, R., S. Brown, S. Hanson, and J. Hinkel, 2010: Economics of Coastal Zone Adaptation to Climate Change. Development and Climate Change, Discussion Paper Number 10, The International Bank for Reconstruction and Development / The World Bank, Washington, DC, USA, 48 pp.

NOAA, 2020: What is a perigean spring tide? National Oceanic and Atmospheric Administration. Available 
at https://oceanservice.noaa.gov/facts/perigean-springtide.html. (Accessed on 1 January 2021)

Poerbondono and Djunarsjah, 2005: Survey of Hydrography, Refika Aditama, Bandung.

Putuhena, W. M. and S. Ginting, 2013: Pengembangan Model Banjir Jakarta (Development on Jakarta Flood Modelling System). Jurnal Teknik Hidraulik, 4, 63-78, doi: 10.32679/jsda.v10i1.144. [Link]

Rimbaman, R. and P. Suparan, 1999: Geomorphology. Coastplan Jakarta Bay Project, Coastal Environmental Geology of the Jakarta Reclamation Project and Adjacent Areas, CCOP COAST PLAN Case Study Report No. 2, Jakarta/Bangkok, 21-25.

Rosenzweig, C. and W. D. Solecki, 2001: Climate Change and a Global City Learning From New York. Environment, 43, 8-18, doi: 10.1080/00139150109605128. [Link]

Sampurno, 2001: Geomorphology and Inundation Areas of DKI Jakarta. Geological Bulletin, 33, 1-12.

SWAN, 2011: User Manual, Faculty of Civil Engineering and Geosciences, Delft University of Technology, Netherlands.
Takagi, H., M. Esteban, T. Mikami, and D. Fujii, 2016: Projection of coastal floods in 2050 Jakarta. Urban Clim., 17, 135-145, doi: 10.1016/j.uclim.2016.05.003. [Link]

The Wamdi Group, 1988: The WAM model-A third generation ocean wave prediction model. J. Phys. Oceanogr., 18, 1775-1810, doi: 10.1175/15200485(1988)018<1775:TWMTGO>2.0.CO;2. [Link]

Tolman, H. L., M. Accensi, H. Alves, F. Ardhuin, J. Bidlot, N. Booij, A. Bennis, T. Campbell, D. Chalikov, A. Chawla, J. Filipot, M. Foreman, P. Janssen, F. Leckler, J. Li, K. Lind, M. Orzech, R. Padilla-Hernández, W. Rogers, A. Rawat, A. Roland, M. D. Sikiric, M. Szyszka, B. Tracy, G. V. Vledder, A. V. Westhuysen, and S. Zieger, 2014: User manual and system documentation of WAVEWATCH III version 4.18. Technical Note, U. S. Department of Commerce, National Oceanic and Atmospheric Administration, National Weather Service, National Centers for Environmental Prediction.

Yahya Surya, M., Z. He, Y. Xia, and L. Li, 2019: Impacts of Sea Level Rise and River Discharge on the Hydrodynamics Characteristics of Jakarta Bay (Indonesia). Water, 11, 1384, doi: 10.3390/w11071384. [Link] 